\begin{tabular}{|c|c|c|}
\hline \multirow{3}{*}{$\begin{array}{r}\text { Case Reports in } \\
\text { Gastroenterology }\end{array}$} & \multirow{2}{*}{\multicolumn{2}{|c|}{ Case Rep Gastroenterol 2020;14:206-211 }} \\
\hline & & \\
\hline & $\begin{array}{l}\text { DOI: } 10.1159 / 000506933 \\
\text { Published online: April 22, } 2020\end{array}$ & $\begin{array}{l}\text { ( } 2020 \text { The Author(s) } \\
\text { Published by S. Karger AG, Basel } \\
\text { www.karger.com/crg }\end{array}$ \\
\hline & $\begin{array}{l}\text { This article is licensed under } t \\
\text { International License (CC BY-N } \\
\text { Usage and distribution for comm }\end{array}$ & $\begin{array}{l}\text { nons Attribution-NonCommercial } 4.0 \\
\text { ger.com/Services/OpenAccessLicense). } \\
\text { uires written permission. }\end{array}$ \\
\hline
\end{tabular}

\title{
Cecal Volvulus: A Rare Cause of Intestinal Obstruction
}

\author{
Carolina Solis Rojas ${ }^{a}$ Ramon Vidrio Duarte ${ }^{b}$ \\ Diego Martín García Vivanco ${ }^{b}$ Eduardo E. Montalvo-Javéc, d \\ aFacultad de Medicina, Universidad Anáhuac México Norte, Huixquilucan de \\ Degollado, Mexico; 'bepartment of General Surgery, Hospital General de México Dr. \\ Eduardo Liceaga, Mexico City, Mexico; 'Hepato-Pancreato-Biliary Unit, Department of \\ General Surgery, Hospital General de México Dr. Eduardo Liceaga, Mexico City, Mexico; \\ ${ }^{\mathrm{d} D e p a r t a m e n t o}$ de Cirugía, Facultad de Medicina, UNAM, Mexico City, Mexico
}

\section{Keywords}

Cecal volvulus · Intestinal obstruction · Hemicolectomy · Surgery

\begin{abstract}
Cecal volvulus is a rare cause of intestinal obstruction, with multifactorial etiologies. This is a case report describing a 52-year-old female with a cecal volvulus diagnosis made during the laparotomy procedure, which was treated with a right hemicolectomy with a side-to-side ileotransverse anastomosis. The aim of this report is to emphasize the importance of a diagnosis and appropriate treatment in this rare pathology in abdominal procedures. In this particular case, the patient benefited from an early surgical intervention without further complications, as well as an adequate postoperative evolution; it is important to acknowledge and consider this pathology during differential diagnosis, and not delay the treatment in patients with cecal volvulus. A critical review of the literature is included and discussed.
\end{abstract}




\section{Introduction}

A volvulus is a potentially life-threatening disease caused by a twisted loop of the bowel and its mesentery on a fixed point [1]. Cecal volvulus was first described by Rokitansky in 1837 [2] as a cause of intestinal strangulation. This type of volvulus presents when the ascending colon and the terminal part of the ileum twist around the mesenteric pedicle [2]. It is responsible for approximately $1 \%$ of all intestinal occlusions, and has a surgical incidence of 2.8-7.1 cases per year per 1 million people [1].

If treatment is delayed, cecal volvulus has a mortality rate as high as $30 \%$. Due to its elevated mortality rate and potential complications, if there is clinical suspicion, even in stable patients, early surgical treatment should be offered.

\section{Case Report}

A 52-year-old female with a history of total hysterectomy due to uterine myomatosis 3 years previously, abdominal wall reconstruction secondary to left paraumbilical hernia with mesh placement 7 years previously, and an appendectomy due to appendicitis complicated with peritonitis 1 year before that, reported by the patient in a retrocecal position, without any other important background to her current clinical condition, presented to the emergency department, reporting obstipation since 3 days. Additionally, 1 day prior to her admission, she also presented with intense and diffuse abdominal pain with abdominal distension, but denied nausea, vomiting, or fever.

During her examination, the vital signs were found to be within normal range. She was hemodynamically stable, and had a soft but distended abdomen with slight pain to palpation attributable to prior administration of IV analgesics. During her emergency department stay, a nasogastric tube was placed and IV fluids were administered. The patient presented an output of $600 \mathrm{~mL}$ of intestinal fluid through the nasogastric tube.

Abdominal X-rays were taken, and they revealed a distended air-filled cecum located centrally within the abdomen, as well as air fluid levels without free intraperitoneal air in the abdominal cavity (Fig. 1). Laboratory tests at her admission reported the following results: glucose $102 \mathrm{mg} / \mathrm{dL}$, urea $41.3 \mathrm{mg} / \mathrm{dL}$, creatinine $0.86 \mathrm{mg} / \mathrm{dL}$, indirect bilirubin $2.13 \mathrm{mg} / \mathrm{dL}$, albumin $3.87 \mathrm{~g} / \mathrm{dL}$, total protein $6 \mathrm{~g} / \mathrm{dL}$, lactate dehydrogenase $364 \mathrm{U} / \mathrm{L}$, amylase $31 \mathrm{U} / \mathrm{L}$, lipase $7 \mathrm{U} / \mathrm{L}$, lactate 2.38 , leukocytes $21.1 \times 10^{9} / \mathrm{L}$, neutrophils $20.5 \times 10^{9} / \mathrm{L}$, hemoglobin $15.6 \times 10^{9} / \mathrm{L}$, hematocrit $46.5 \%$, and platelets $273,000 / \mathrm{mm}^{3}$; the rest of the laboratory tests showed no abnormalities.

Urgent laparotomy followed, and purulent fluid collection was observed and the cecum was found twisted counterclockwise and folded up over itself in an anteromedial orientation, showing a necrotic back wall, without perforation signs. Right hemicolectomy was performed with a side-to-side ileotransverse anastomosis (Fig. 2). Furthermore, a final washout was carried out, without any further findings. The surgery was considered to be completed, and the surgical specimen was sent for histopathological analysis (Fig. 3).

The patient had an adequate postoperative evolution, with a decrease in leukocyte count to 10,534 , maintaining a double antibiotic scheme with ceftazidime and metronidazole. A liquid diet was initiated $48 \mathrm{~h}$ after the surgery. When the patient had adequate peristalsis, she was then progressed to a soft diet $24 \mathrm{~h}$ after liquid tolerance was achieved. The patient was kept without clinical signs of anastomotic leakage. At day 6, her discharge was decided. 
After 10 days, a final histopathological examination was performed, reporting a tubular, smooth, shiny, grayish-brown piece measuring $25 \times 12 \times 6 \mathrm{~cm}$, considered to be the cecal and terminal ileum. The edges were anfractuous and violaceous, and dilation of the lumen was identified. The mucosal surface was observed to be composed of multiple grayish-brown mucosal folds, semi-rough, $10 \mathrm{~cm}$ from the proximal edge when cut. There was an area which showed a flattening of the folds with a violaceous color that was tender to the touch, accompanied by green, thick cream. Representative cuts were made, with ulcerated lesions being observed in the mucosal surface. As an outcome, the histopathological diagnosis was established as severe pseudomembranous colitis, accompanied by acute and chronic peritonitis.

In the postoperative assessment after 4 months, the patient was found to be tolerating oral intake, was asymptomatic, and did not have any signs of weight loss. It was decided to perform an ambulatory colonoscopy, which showed postoperative changes without narrowing anastomosis and no findings of inflammatory bowel disease.

\section{Discussion}

Cecal volvulus is a torsion, usually of $360^{\circ}$, of a segment of the colon on its mesenteric axis, which causes strangulation - hence, an occlusion of the two ends of the volvulated segment - compromising its blood irrigation, which causes an obstruction in a closed loop [3, 4]. There are two types of cecal volvulus [5, 6]. The first and most frequent type $(90 \%)$ is the conventional axial rotation of the cecum, mostly counterclockwise, with involvement of the ileum. Secondly, there is cecal bascule, in which the cecum rotates upward and anteriorly in the horizontal plane without any torsion whatsoever $[7,8]$.

Colonic volvulus is the most common type of volvulus, followed by that of the sigmoid colon and cecum, and there are case reports involving the transverse colon including the splenic or hepatic angle $[4,9,10]$.

Different risk factors and etiologies have been described for the development of this pathology that vary between populations; the most common associated factors are chronic constipation, a high-residue diet, laxative abuse, pregnancy, and Chagas disease, among others, which are mentioned throughout different studies [9].

In this particular case, it is considered that the history of appendectomy could have been a predisposing factor, given that the surgical approach to an appendix in a retrocecal position may lead to the release of the cecum for optimal mobility by sectioning Toldt's fascia. With this in mind, and the presence of constipation, the surgical history might have been a key factor for this particular clinical scenario.

Regarding clinical manifestations, patients may often present with severe abdominal pain, distension, constipation, nausea, and vomiting that even could cause hypovolemic shock $[11,12]$. On physical examination, a distended abdomen could be observed, generalized tympany perceived, and a hypoactive or absence of peristaltic sounds found. On the other hand, if perforation or gangrene occurs, a patient will present with clinical findings of acute abdominal pain, with signs of peritoneal irritation and hemodynamic instability [13].

In contrast to sigmoid volvulus, for cecal volvulus, abdominal X-ray imaging has limited utility, identifying in some cases air fluid levels and predominant cecum dilation, while in fewer cases the cecum is displaced into the right upper quadrant; hence, surgeons must decide whether an additional imaging study or an immediate surgical procedure is needed. CT scanning nowadays has an important role, with a sensibility as high as $90 \%$ for cecal volvulus; a swirl of mesenteric soft tissue and fat attenuation with adjacent loops of bowel surrounding 
rotated intestinal vessels, known as the "whirl sign," is almost diagnostic. Nevertheless, it is only present in few cases of classic volvulus. Regarding cecal bascule, CT scanning has a lower sensibility, and at least $50 \%$ of bascule diagnoses are made during exploratory laparotomy [3, 9]. Although abdominal tomography is more reliable than abdominal radiography [14], in some cases, with the initial radiologic findings, patients could undergo emergency surgery [10].

There is no consensus on the best management strategy; nonetheless, the low success rates of colonoscopy for reduction of a volvulated cecum and the risk of perforation alongside the potential risk of missing colonic necrosis support surgical management as the most reliable treatment for this pathology.

Regarding the surgical treatment of choice, right colectomy has become the most effective procedure, with the lowest recurrence rates and an acceptable morbidity risk. Some algorithms have been published which put an emphasis on the patient's clinical condition and the presence of necrosis or perforation. As alternative procedures, detorsion with cecopexy, cecostomy, and ileocecectomy are the most common procedures mentioned. When a right colectomy is performed, the performance of a primary anastomosis depends on the hemodynamic conditions and grade of contamination [15].

Cecal volvulus is not a common cause of colonic obstruction with multifactorial etiologies. A diagnosis should be obtained quickly by physical examination and radiological findings. Treatment consists of urgent surgery to diminish the mortality rate.

\section{Statement of Ethics}

The authors declare that no experiments were performed on humans or animals for this study. The authors declare that they have followed the protocols of their work center on the publication of patient data, and the patient has given written informed consent to publish her case.

\section{Disclosure Statement}

The authors declare that they have no conflicts of interest.

\section{Funding Sources}

This work did not receive any kind of financial support from any source.

\section{Author Contributions}

All the authors contributed to the design and implementation of the research, to the analysis of the results, and to the writing of the manuscript. 


\section{References}

1 Rodríguez-Hermosa JI, Martín A, Farrés R, Pont J, Codina-Cazador A, Ruiz B, et al. Obstrucción intestinal por vólvulo de ciego. Cir Esp. 2005;78(6):385-7.

2 Rokitansky C. Intestinal strangulation. Arch Gen Med. 1837;14:202-4.

3 Tejler G, Jiborn H. Volvulus of the cecum. Report of 26 cases and review of the literature. Dis Colon Rectum. 1988 Jun;31(6):445-9.

4 Peterson HI. Volvulus of the cecum. Ann Surg. 1967 Aug;166(2):296-9.

5 Cózar Ibáñez A, Medina Cuadros M, del Olmo Escribano M, Moreno Montesinos JM, Martínez Gallego G. Vólvulo cecal en el síndrome de Cornelia de Lange. Rev Esp Enferm Dig. 2004 Jan;96(1):85-6.

6 Utrillas AC, López M, Rebollo J, Minguillón A, Moreno C, Del Vall JM. Vólvulo de ciego: una rara causa de obstrucción intestinal. Cir Esp. 2003;74 Suppl 1:120.

7 Echenique Elizondo M, Amondaraín Arratíbel JA. Vólvulos de intestino grueso. Rev Esp Enferm Dig. 2002 Apr;94(4):201-10.

8 Güller U, Zuber M, Harder F. Cecal volvulus - a frequently misdiagnosed disease picture. Results of a retrospective study of 26 patients and review of the literature [in German]. Swiss Surg. 2001;7(4):158-64.

9 Frizelle FA, Wolff BG. Colonic volvulus. Adv Surg. 1996;29:131-9.

10 Madiba TE, Thomson SR, Church JM. The management of cecal volvulus. Dis Colon Rectum. 2002 Feb;45(2):264-7.

11 Ballantyne GH, Brandner MD, Beart RW Jr, Ilstrup DM. Volvulus of the colon. Incidence and mortality. Ann Surg. 1985 Jul;202(1):83-92.

12 Tirol FT. Cecocolic torsion: classification, pathogenesis, and treatment. JSLS. 2005 Jul-Sep;9(3):328-34

13 Hiltunen KM, Syrjä H, Matikainen M. Colonic volvulus. Diagnosis and results of treatment in 82 patients. Eur J Surg. 1992 Nov-Dec;158(11-12):607-11.

14 Renzulli P, Maurer CA, Netzer P, Büchler MW. Preoperative colonoscopic derotation is beneficial in acute colonic volvulus. Dig Surg. 2002;19(3):223-9.

15 Osiro SB, Cunningham D, Shoja MM, Tubbs RS, Gielecki J, Loukas M. The twisted colon: a review of sigmoid volvulus. Am Surg. 2012 Mar;78(3):271-9.

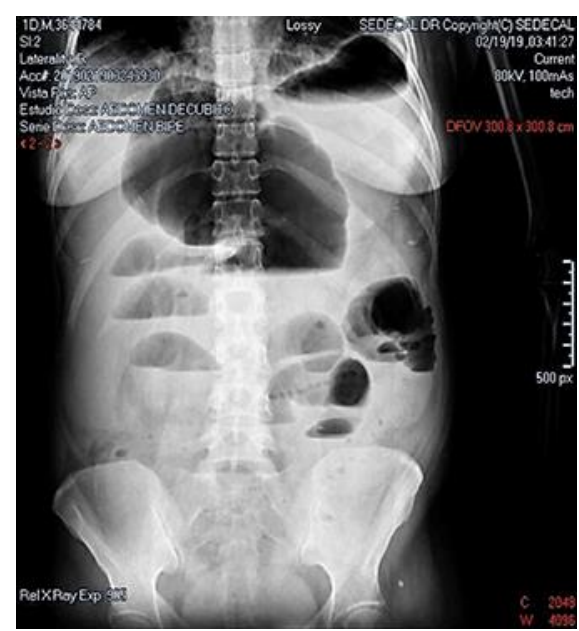

Fig. 1. Abdominal X-ray image showing air fluid levels and predominant cecum dilation. 


\begin{tabular}{|c|c|c|}
\hline \multirow{2}{*}{$\begin{array}{l}\text { Case Reports in } \\
\text { Gastroenterology }\end{array}$} & \multicolumn{2}{|c|}{ Case Rep Gastroenterol 2020;14:206-211 } \\
\hline & DOI: 10.1159/000506933 & $\begin{array}{l}\text { O } 2020 \text { The Author(s). Published by S. Karger AG, Basel } \\
\text { www.karger.com/crg }\end{array}$ \\
\hline
\end{tabular}

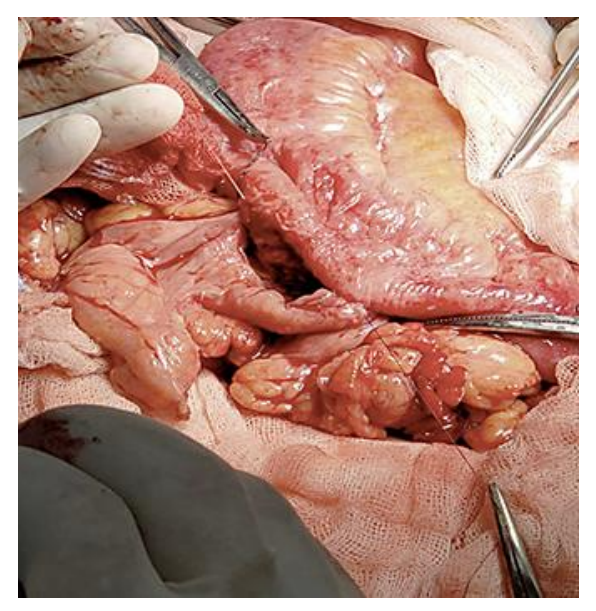

Fig. 2. Manual side-to-side ileotransverse anastomosis.

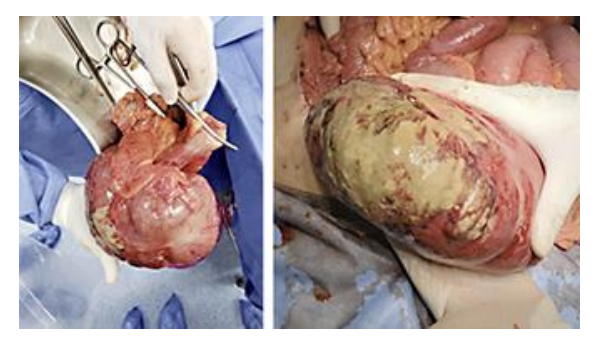

Fig. 3. Surgical piece of the cecum with posterior wall necrosis showing pustular-necrotic fibers sent to the pathology department. 